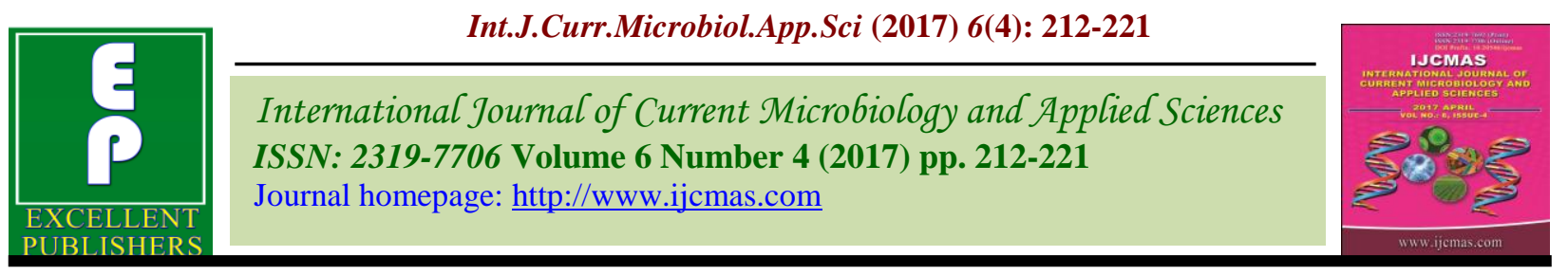

Original Research Article https://doi.org/10.20546/ijcmas.2017.604.025

\title{
Effect of Time of Harvest, Method of Harvest and Pre Packaging Calcium Chloride Treatments on Shelf Life and Quality of Moringa (Moringa oleifera Lam.) CV. PKM 1
}

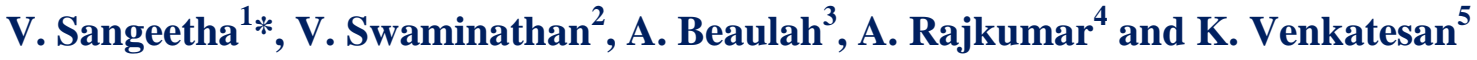 \\ ${ }^{1}$ Tamil Nadu Agricultural University, Coimbatore - 641 003, India \\ ${ }^{2} \mathrm{AC} \& \mathrm{RI}, \mathrm{TNAU}$, Madurai, India \\ ${ }^{3} \mathrm{HC} \& \mathrm{RI}$, TNAU, Coimbatore, India \\ ${ }^{4}$ Tamil Nadu Agricultural University, Coimbatore 641 003, India \\ ${ }^{5} \mathrm{AC} \& \mathrm{RI}$, Trichy, India \\ *Corresponding author
}

A B S T R A C T

Keywords

Moringa, Firmness,

Shelf life,

Biochemical

changes.

Article Info

Accepted:

02 March 2017

Available Online:

10 April 2017
Moringa is one of the important vegetable in the human diet of south Indian people. But it is having short shelf life of maximum 3 days at ambient condition with freshness, firmness and retains its nutritional quality. So we are in need to extend the shelf life of Moringa. The investigation was under taken in Horticultural College and Research Institute, Periyakulam during 2010-2011. The experiment was laid out in completely randomized design. To extend the shelf life of moringa cv. PKM1, they were harvested in different times of a day viz., morning time, afternoon time, evening time and also harvested with and without pedicel. Then they were pre-treated with $\mathrm{CaCl}_{2}$ at $0.5 \%, 1.0 \%$ and $2.0 \%$ concentration. Untreated pods were kept as control. However, among the 24 treatmental combinations $\mathrm{T}_{1} \mathrm{M}_{1} \mathrm{P}_{3}$ (Pods harvested at morning (7.00 to $9.00 \mathrm{am}$ ) with pedicel and treated with $1.0 \% \mathrm{CaCl}_{2}$ ) recorded minimum weight loss and had the shelf life of nine days under ambient temperature. They retain its colour, firmness at ambient condition.

\section{Introduction}

Moringa is a multipurpose tree, wherein the leaves, flowers and fruits are used for culinary and medicinal purposes. Invention of annual moringa cv. PKM-1 is a milestone in the research on moringa by which the area and productivity were greatly increased. It has occupied considerable area in adjoining states like Karnataka and Andhra Pradesh (Vijayakumar, 2003). Over the past two decades, many reports have appeared in mainstream scientific journals describing its nutritional and medicinal properties.
Nutritional analysis indicates that moringa leaves contain a wealth of essential, disease preventing nutrients. They even contain all of the essential amino acids, which is unusual for a plant source. Since the dried leaves are concentrated, they contain higher amounts of many of these nutrients except Vitamin C (Faizi, 1998). This much valuable crop has very short shelf life and also loss in nutritional quality due to poor postharvest handling and different means of food preparation influence the nutritional and functional qualities of moringa. 
Moringa is one of the most important crop in south India and cultivated in large area. Due to absence of proper post-harvest management system, bulk quantity of moringa gets damaged during the process of handling, transportation and marketing. Rakhshinda Panda et al., (2010) reported that the green chillies are picked early in the morning or in the evening. These are protected from the sun to avoid quality deterioration. Samuel (2011) stated that the tomatoes harvested late in the afternoon and graded and put the fruits in boxes for the early market of the following day. The tomatoes harvested during the hot period of the day have shorter shelf life than tomatoes harvested early in the morning and late in the afternoon.

Singh et al., (1993) have reported longer shelf life and better marketability of tomatoes having a small pedicel along with calyx. Fruits harvested with stalk resulted into lower PWL as compared to those without stalk. The reason behind the higher loss associated with the fruits harvested without stalk and stored under ambient condition might be due to more decay loss as exposed surface of stalk or scar left at the time of harvesting creates avenue for the entry of pathogen.

A recent study conducted to enhance the shelf life of moringa by pre packaging treatment with $\mathrm{CaCl}_{2}$ at different concentrations of $0.0 \%$ (control), $0.5 \%, 1.0 \%$ and $2.0 \%$. This technique to be adopted to increase the shelf life and utilization of this vegetable avoiding the post harvest losses, moreover, post harvest treatments play a significant role in extending the shelf-life of fruits. Among the chemical treatments calcium chloride has significant influence on shelf life. Giraldo et al., (1977) reported that in many countries of the world, fruits and vegetables are washed in chlorine or potassium permanganate before packaging. It is done in order to reduce micro flora, especially bacteria from the produce. Tirmazi and Wills (1982) reported that the calcium treatments significantly influenced the shelf life of tomato fruits. As the concentration of calcium increased, the shelf life of fruits increased. The maximum shelf life (16.50 days) was noticed in $1 \%$ calcium chloride treated fruits compared to the control (11 days). Davoodi et al., (2007) reported that the $\mathrm{CaCl}_{2}$ preserved a pure red colour, in which carotenoid pigments could be retained. Adding of $\mathrm{CaCl}_{2}$ was found to improve the red colour stability, as $\mathrm{CaCl}_{2}$ may react with water molecules resulting in increased water mobility and reduced drying time and the pretreatment of fresh vegetables by various antimicrobial agents decrease the density of microbial contaminant from the surface (Pradnya, 2008). Therefore, the present study has been carried out to study various physicochemical changes during storage period and to identify a suitable post-harvest treatment for extending the shelf-life of moringa.

\section{Materials and Methods}

Matured green pods of uniform size, colour, and texture, free from injuries and blemishes of annual moringa PKM 1 were harvested from western block of Horticultural College And Research Institute, Periyakulam. Pods of moringa with $5.00 \mathrm{~cm}$ pedicle and without pedicle were harvested at different times of a day viz., morning (7.00 to $9.00 \mathrm{am}$ ), afternoon (12.00 to $2.00 \mathrm{pm})$ and evening (04.00 to $06.00 \mathrm{pm})$. Pods of moringa were harvested from different trees and the selected pods free from bruises, cuts, rots, and other damages were cleaned in running tap water and kept on the news papers to absorb moisture over the pods. Then the pods were used for experiment. The pre packaging treatment was done with calcium chloride in different concentration viz., $0.5 \%, 1.0 \%, 2.0 \%$ and they are compared with control (untreated 
pods). $\mathrm{T}_{1}$ : Harvesting at morning 7.00 am9.00 am. $\mathrm{T}_{2}$ : Harvesting at afternoon 12.00 pm-02.00 pm. $\mathrm{T}_{3}$ : Harvesting at evening $04.00 \mathrm{pm}-06.00 \mathrm{pm} . \mathrm{M}_{1}$ : Harvesting without pedicel. $\mathrm{M}_{2}$ : Harvesting with pedicel. $\mathrm{P}_{1}$ : Treatments are Pre treatment without $\mathrm{CaCl}_{2}$ (Control). $\mathrm{P}_{2}$ : Pre treatment with $\mathrm{CaCl}_{2} \quad 0.5 \%$ concentration, $\mathrm{P}_{3}$ : Pre treatment with $\mathrm{CaCl}_{2}$ $1.0 \%$ concentration, $\mathrm{P}_{4}$ : Pre treatment with $\mathrm{CaCl}_{2} 2.0 \%$ concentration. Initial records of firmness, colour, ascorbic acid, calcium and crude fibre and all these parameters were again recorded finally (pods starts to decay). The initial weight of the pod was noted before storage. The loss in weight was recorded in the alternate days of storage. Expressed in terms of grams $(\mathrm{g})$, the firmness of the pod was measured by using penetrometer. Number of days stored was calculated from initial day of storage to till the commodity was found to be marketable. The ascorbic acid content was estimated as per the method described by Hameed et al., (1998). The Crude fibre content was estimated as per the method described by Maynard (1970). The calcium and iron content of pod was estimated as per the method described by Jackson (1973).

\section{Results and Discussion}

\section{Physiological loss in weight}

The study indicated that PLW \% increased significantly with increases in storage period. The time of harvest had the significant influence on the weight loss of moringa pod. The morning harvested pods shows minimum weight loss $(10.37 \%)$ at nine days after storage under ambient condition it might be because of the morning harvested pods had minimum water loss when compared to afternoon or evening harvest (Table 1). In case of less water loss the turgidity was maintained which has resulted in less physiological loss in weight. Similar results were reported by Palada (2003) in amaranthus. The method of harvest also had significant effect on physiological loss in weight. Harvesting of moringa with pedicle recorded minimum weight loss (11.25\%) when compared to without pedicle (13.31\%). This might be because of higher loss associated with the pods harvested without stalk and stored under ambient condition would have produced more decay loss as exposed surface of stalk or scar left at the time of harvesting creates avenue for the entry of pathogen. Pathak and Shrivastava (1969) and Singh et al., (1993) have concluded similar explanation in mango. The effect of post harvest treatments showed that, the calcium chloride $(1 \%)$ treated pods recorded minimum weight loss $(9.12 \%)$ when compared to untreated moringa pods (15.59\%). The calcium chloride treated pods recorded minimum physiological weight loss. It might be due to $\mathrm{CaCl}_{2}$ might react with water molecules and it might be acting in some manner to block the amino groups before entering into the enzymatic browning reaction. This result was supported by Davoodi et al., (2007) in tomato.

The combined effect of morning harvest with pedicle and pre packaging treatment with calcium chloride (1\%) $\left(\mathrm{T}_{1} \mathrm{M}_{1} \mathrm{P}_{3}\right)$ had significant influence on physiological loss in weight $(6.61 \%)$ of moringa at four days after storage. This might be due to combined effect of morning harvest, with pedicle and $\mathrm{CaCl}_{2}$ treatment which influence the storage (Table $1)$.

\section{Colour and firmness}

The time of harvest had the significant influence on colour and firmness (Tables 1 and 2). The morning harvested pods retains more moisture when compared to afternoon and evening harvested pods. If the moisture loss is less, then the deterioration in colour also decreased, because moisture content 
retains the highest values of colour (8.02) and also it maintains the firmness (22.02) of moringa. Similar result was supported by Ali (2004) in tomato.

The method of harvest also had significant effect on colour and firmness. The moringa pods harvested with pedicle retains its colour (7.85) and firmness (22.18). This might be due to the reasons attributed to the fact that the pedicle stores certain amount of chlorophyll and food required for respiration after harvest and the destruction process starts at the pedicle end. Hence the pod would have retained colour. The effect of post harvest treatments showed that, the calcium chloride $(1 \%)$ treated pods $\left(\mathrm{T}_{1} \mathrm{M}_{1} \mathrm{P}_{3}\right)$ recorded highest score in pod colour (8.46) and also had good firmness (23.52). This might be due to addition of $\mathrm{CaCl}_{2}$ was found to improve the green colour stability, as $\mathrm{CaCl}_{2}$ might react with cell wall and retains firmness, it would have delayed the chlorophyll destruction in the pods and prolong the time taken for drying. This study was in line with the observation of Davoodi et al., (2007) in tomato who suggested that calcium might be acting in some manner to block the amino groups before entering into the enzymatic browning reaction. The similar result was given by Wiriya, (2009) in chillies. So the $\mathrm{CaCl}_{2}$ treated pods maintains the colour and firmness of the moringa pods during storage. The combined effect of morning harvest with pedicle and pre packaging treatment with calcium chloride had significant influence on colour and firmness of moringa it might be because of all the above said season.

\section{Shelf life}

The time of harvest had the significant influence on shelf life of moringa. Morning harvested pods were best in retaining the shelf life (5.57) when compared to evening (4.80) and afternoon (2.96) harvest (Table 2). Pods harvested at mid day or mid afternoon had poor keeping quality, owing to their high respiration rates. Singh et al., (1993) in mango. The method of harvest also had significant effect on shelf life of moringa. Moringa pods harvested with stalk could prolong the shelf life (5.03) as compared to those harvested without stalk (3.85). This might be due to the pedicel slows down the process of oxidation of metabolites from the pods. Similar findings were reported by Wills and Tirmazi (1982) in tomato. Treating the moringa pods with calcium chloride at the rate of $(1 \%)$ could extend the shelf life (7.52). This might be due to the calcium chloride binds with cell wall and changes to calcium pectate. The calcium pectate acts as a barrier of moisture loss and slows down the rate of respiration in ambient condition. The combined effect of time and method of harvest had significant influence on shelf life of moringa. This could be due to reduction in moisture loss which influenced the shelf life.

\section{Changes in chemical constituents during storage}

The time and method of harvest had significant influence on ascorbic acid crude, fibre and protein content during the period of storage (Table 3). This might be due to less field heat in morning time which may reduce the evaporation of water from the pods and the pedicle prevents faster nutrient loss from the pods. The calcium chloride treatment had significant effect on the ascorbic acid, crude fibre and protein content of pods during storage. This might be due the fact that calcium chloride reduces the lignifications process and had moisture retention and cell wall thickening. This may not allow the reduction of ascorbic acid, protein and slow down the crude fibre formation. So, that in control there had been faster increase in crude fibre content when compared to treated pods. Concurrent results were reported by Simal (2005) in red pepper. 
Table.1 Effect of different time of harvest, method of harvest and pre packaging treatment with $\mathrm{CaCl}_{2}$ on physiological loss of weight (\%) pod colour of moringa cv.PKM 1

\begin{tabular}{|c|c|c|c|c|c|c|c|c|c|c|}
\hline \multirow[t]{2}{*}{ Treatments } & \multicolumn{5}{|c|}{ PLW (\%) 0-9 Days After Storage } & \multicolumn{5}{|c|}{ Pod Colour (9 Days After Storage) } \\
\hline & $\mathbf{P}_{1}$ & $\mathbf{P}_{2}$ & $\mathbf{P}_{3}$ & $\mathbf{P}_{4}$ & MEAN & $\mathbf{P}_{1}$ & $\mathbf{P}_{2}$ & $\mathbf{P}_{3}$ & $\mathbf{P}_{4}$ & MEAN \\
\hline $\mathbf{T}_{1}$ & 13.39 & 12.47 & 7.61 & 8.01 & 10.37 & 7.91 & 7.95 & 8.16 & 8.06 & 8.02 \\
\hline $\mathbf{T}_{2}$ & 18.39 & 17.59 & 11.24 & 11.74 & 14.74 & 6.12 & 6.27 & 7.55 & 7.49 & 6.86 \\
\hline $\mathbf{T}_{3}$ & 15.01 & 14.42 & 8.52 & 9.00 & 11.74 & 7.67 & 7.91 & 8.02 & 7.99 & 7.90 \\
\hline MEAN & 15.59 & 14.83 & 9.12 & 9.58 & 12.28 & 7.23 & 7.38 & 7.91 & 7.85 & 7.59 \\
\hline $\mathbf{M}_{1}$ & 14.35 & 13.77 & 8.21 & 8.67 & 11.25 & 7.46 & 7.67 & 8.15 & 8.11 & 7.85 \\
\hline $\mathbf{M}_{2}$ & 16.84 & 15.89 & 10.03 & 10.49 & 13.31 & 7.00 & 7.08 & 7.67 & 7.59 & 7.33 \\
\hline MEAN & 15.59 & 14.83 & 9.12 & 9.58 & 12.28 & 7.23 & 7.38 & 7.91 & 7.85 & 7.59 \\
\hline $\mathbf{T}_{\mathbf{1}} \mathbf{M}_{1}$ & 11.72 & 11.23 & 6.61 & 6.99 & 9.14 & 8.31 & 8.36 & 8.46 & 8.42 & 8.38 \\
\hline $\mathbf{T}_{\mathbf{1}} \mathbf{M}_{2}$ & 15.06 & 13.72 & 8.62 & 9.02 & 11.60 & 7.51 & 7.54 & 7.86 & 7.71 & 7.65 \\
\hline $\mathbf{T}_{2} \mathbf{M}_{1}$ & 17.97 & 17.15 & 10.41 & 10.92 & 14.11 & 6.23 & 6.34 & 7.57 & 7.52 & 6.91 \\
\hline $\mathbf{T}_{\mathbf{2}} \mathbf{M}_{2}$ & 18.81 & 18.03 & 12.06 & 12.57 & 15.37 & 6.01 & 6.21 & 7.54 & 7.47 & 6.80 \\
\hline $\mathbf{T}_{3} \mathbf{M}_{1}$ & 13.37 & 12.93 & 7.61 & 8.11 & 10.50 & 7.86 & 8.32 & 8.42 & 8.39 & 8.24 \\
\hline $\mathbf{T}_{3} \mathbf{M}_{2}$ & 16.64 & 15.92 & 9.43 & 9.88 & 12.97 & 7.48 & 7.51 & 7.63 & 7.59 & 7.55 \\
\hline MEAN & 15.59 & 14.83 & 9.12 & 9.58 & 12.28 & 7.23 & 7.38 & 7.91 & 7.85 & 7.59 \\
\hline SOURCE & \multicolumn{3}{|c|}{ SEd } & \multicolumn{2}{|c|}{ CD (0.05) } & \multicolumn{3}{|c|}{ SEd } & \multicolumn{2}{|c|}{ CD (0.05) } \\
\hline $\mathbf{T}$ & \multicolumn{3}{|c|}{0.00871} & \multicolumn{2}{|c|}{0.01797} & \multicolumn{3}{|c|}{0.005} & \multicolumn{2}{|c|}{0.010} \\
\hline $\mathbf{M}$ & \multicolumn{3}{|c|}{0.00711} & \multicolumn{2}{|c|}{0.01467} & \multicolumn{3}{|c|}{0.004} & \multicolumn{2}{|c|}{0.008} \\
\hline $\mathbf{P}$ & \multicolumn{3}{|c|}{0.01005} & \multicolumn{2}{|c|}{0.02075} & \multicolumn{3}{|c|}{0.006} & \multicolumn{2}{|c|}{0.012} \\
\hline TM & \multicolumn{3}{|c|}{0.01231} & \multicolumn{2}{|c|}{0.02541} & \multicolumn{3}{|c|}{0.008} & \multicolumn{2}{|c|}{0.017} \\
\hline $\mathbf{T P}$ & \multicolumn{3}{|c|}{0.01741} & \multicolumn{2}{|c|}{0.03593} & \multicolumn{3}{|c|}{0.011} & \multicolumn{2}{|c|}{0.023} \\
\hline MP & \multicolumn{3}{|c|}{0.01422} & \multicolumn{2}{|c|}{0.02934} & \multicolumn{3}{|c|}{0.009} & \multicolumn{2}{|c|}{0.019} \\
\hline TMP & & .02462 & & 0.0 & 82 & & & & 0.1 & \\
\hline $\begin{array}{l}\mathrm{T}_{1} \text { - Harvesting at morr } \\
\mathrm{T}_{2} \text {-Harvesting at afterr } \\
\mathrm{T}_{3} \text {-Harvesting at eveni }\end{array}$ & $\begin{array}{l}\text { am-9.0 } \\
00 \text { pm-0 } \\
\text { pm-06. }\end{array}$ & $\begin{array}{l}\mathrm{am} \\
00 \mathrm{pm} \\
\mathrm{pm}\end{array}$ & & $\begin{array}{l}\mathrm{I}_{1}-\text { Harvest } \\
\mathbf{M}_{2} \text { - Harves }\end{array}$ & $\begin{array}{l}\text { without pec } \\
\text { g With pedi }\end{array}$ & & $\begin{array}{l}\text { 1- Pre } \\
\text { 2- Pre } \\
\text { 3- Pre } \\
\text { 4- Pre }\end{array}$ & $\begin{array}{l}\text { ent with } \\
\text { ent with } \\
\text { ent with } \\
\text { nt with }\end{array}$ & $\begin{array}{l}\mathrm{Cl}_{2}(\mathrm{C} \\
\mathrm{CaCl}_{2} \\
\mathrm{CaCl}_{2} \\
\mathrm{CaCl}_{2}\end{array}$ & \\
\hline
\end{tabular}


Table.2 Effect of different time of harvest, method of harvest and pre packaging treatment with $\mathrm{CaCl}_{2}$ firmness and shelf life (no. of days) of Moringa cv.PKM 1

\begin{tabular}{|c|c|c|c|c|c|c|c|c|c|c|}
\hline \multirow[t]{2}{*}{ Treatments } & \multicolumn{5}{|c|}{ Firmmess 0-9 Days After Storage } & \multicolumn{5}{|c|}{ Shelf life (days) } \\
\hline & $\mathbf{P}_{1}$ & $\mathbf{P}_{2}$ & $\mathbf{P}_{3}$ & $\mathbf{P}_{4}$ & MEAN & $\mathbf{P}_{1}$ & $\mathbf{P}_{2}$ & $\mathbf{P}_{3}$ & $\mathbf{P}_{4}$ & MEAN \\
\hline $\mathbf{T}_{1}$ & 21.41 & 21.81 & 22.61 & 22.27 & 22.02 & 4.41 & 5.93 & 9.98 & 7.95 & $\mathbf{5 . 5 7}$ \\
\hline $\mathbf{T}_{2}$ & 19.05 & 19.51 & 20.83 & 20.43 & 19.95 & 2.40 & 3.50 & 4.85 & 4.38 & 2.96 \\
\hline $\mathbf{T}_{3}$ & 20.59 & 21.00 & 22.37 & 21.37 & 21.33 & 4.48 & 5.45 & 7.73 & 6.20 & 4.80 \\
\hline MEAN & 20.35 & 20.77 & 21.94 & 21.35 & 21.10 & 3.76 & 4.96 & 7.52 & 6.18 & 4.44 \\
\hline $\mathbf{M}_{1}$ & 21.40 & 21.82 & 22.99 & 22.52 & 22.18 & 4.57 & 5.75 & 8.13 & 6.73 & 5.03 \\
\hline $\mathbf{M}_{2}$ & 19.30 & 19.72 & 20.89 & 20.19 & 20.02 & 2.95 & 4.17 & 6.90 & 5.62 & 3.85 \\
\hline MEAN & 20.35 & 20.77 & 21.94 & 21.35 & 21.10 & 3.76 & 4.96 & 7.52 & 6.18 & 4.44 \\
\hline $\mathbf{T}_{\mathbf{1}} \mathbf{M}_{1}$ & 22.11 & 22.61 & 23.52 & 23.20 & 22.86 & 5.56 & 7.15 & 10.40 & 8.60 & 6.31 \\
\hline $\mathbf{T}_{\mathbf{1}} \mathbf{M}_{2}$ & 20.71 & 21.01 & 21.70 & 21.33 & 21.19 & 3.25 & 4.70 & 9.55 & 7.30 & 4.83 \\
\hline $\mathbf{T}_{2} \mathbf{M}_{1}$ & 20.05 & 20.42 & 22.12 & 21.71 & 21.07 & 2.70 & 3.70 & 5.55 & 4.45 & 3.26 \\
\hline $\mathbf{T}_{\mathbf{2}} \mathbf{M}_{2}$ & 18.05 & 18.61 & 19.55 & 19.15 & 18.84 & 2.10 & 3.30 & 4.15 & 4.30 & 2.65 \\
\hline $\mathbf{T}_{3} \mathbf{M}_{1}$ & 22.05 & 22.45 & 23.33 & 22.65 & 22.62 & 5.45 & 6.40 & 8.45 & 7.15 & 5.52 \\
\hline $\mathbf{T}_{3} \mathbf{M}_{2}$ & 19.14 & 19.55 & 21.42 & 20.10 & 20.05 & 3.50 & 4.50 & 7.00 & 5.25 & 4.07 \\
\hline MEAN & 20.35 & 20.77 & 21.94 & 21.35 & 21.10 & 3.76 & 4.96 & 7.52 & 6.18 & 4.44 \\
\hline SOURCE & \multicolumn{3}{|c|}{ SEd } & \multicolumn{2}{|c|}{ CD (0.05) } & \multicolumn{3}{|c|}{ SEd } & \multicolumn{2}{|c|}{ CD (0.05) } \\
\hline $\mathbf{T}$ & \multicolumn{3}{|c|}{0.01949} & \multicolumn{2}{|c|}{0.04022} & \multicolumn{3}{|c|}{0.09599} & \multicolumn{2}{|c|}{0.19812} \\
\hline $\mathbf{M}$ & \multicolumn{3}{|c|}{0.01591} & \multicolumn{2}{|c|}{0.03284} & \multicolumn{3}{|c|}{0.07838} & \multicolumn{2}{|c|}{0.16176} \\
\hline $\mathbf{P}$ & \multicolumn{3}{|c|}{0.02250} & \multicolumn{2}{|c|}{0.04644} & \multicolumn{3}{|c|}{0.11084} & \multicolumn{2}{|c|}{0.22877} \\
\hline TM & \multicolumn{3}{|c|}{0.02756} & \multicolumn{2}{|c|}{0.05687} & \multicolumn{3}{|c|}{0.13575} & \multicolumn{2}{|c|}{0.28018} \\
\hline $\mathbf{T P}$ & \multicolumn{3}{|c|}{0.03897} & \multicolumn{2}{|c|}{0.08043} & \multicolumn{3}{|c|}{0.19199} & \multicolumn{2}{|c|}{0.39624} \\
\hline MP & \multicolumn{3}{|c|}{0.03182} & \multicolumn{2}{|c|}{0.06567} & \multicolumn{3}{|c|}{0.15676} & \multicolumn{2}{|c|}{0.32353} \\
\hline TMP & & 0.05511 & & 0.1 & & & 151 & & 0.56 & \\
\hline $\begin{array}{l}\mathrm{T}_{1}-\text { Harvesting at mor } \\
\mathrm{T}_{2}-\text { Harvesting at after } \\
\mathrm{T}_{3} \text {-Harvesting at even }\end{array}$ & $\begin{array}{l}00 \mathrm{am}-9 . \\
2.00 \mathrm{pm}- \\
00 \mathrm{pm}-0\end{array}$ & $\begin{array}{l}0 \mathrm{am} \\
2.00 \mathrm{pm} \\
.00 \mathrm{pm}\end{array}$ & & $\begin{array}{l}\text { 1- Harves } \\
\text { 2- Harves }\end{array}$ & $\begin{array}{l}\text { without } p \\
\text { With pedi }\end{array}$ & & $\begin{array}{l}\text { Pre trea } \\
\text { Pre trea } \\
\text { Pre trea } \\
\text { Pre trea }\end{array}$ & $\begin{array}{l}\text { without } \\
\text { with } 0 . \\
\text { with } 1 . \\
\text { with } 2 .\end{array}$ & $\begin{array}{l}\mathrm{l}_{2} \text { (Con } \\
\mathrm{aCl}_{2} \\
\mathrm{aCl}_{2} \\
\mathrm{aCl}_{2}\end{array}$ & \\
\hline
\end{tabular}


Table.3 Effect of different time of harvest, method of harvest and pre packaging treatment with $\mathrm{CaCl}_{2}$ on biochemical changes during storage of moringa cv.PKM 1

\begin{tabular}{|c|c|c|c|}
\hline Treatments & $\begin{array}{l}\text { Ascorbic Acid } \\
\text { (mg/100 g) }\end{array}$ & $\begin{array}{c}\text { Protein } \\
(\mathrm{mg} / 100 \mathrm{~g})\end{array}$ & $\begin{array}{c}\text { Crude Fibre } \\
\text { (g/100 g) }\end{array}$ \\
\hline $\mathrm{T}_{1} \mathrm{M}_{1} \mathrm{P}_{1}$ & 116.97 & 1.49 & 4.99 \\
\hline $\mathrm{T}_{1} \mathrm{M}_{1} \mathrm{P}_{2}$ & 117.51 & 2.22 & 4.96 \\
\hline $\mathrm{T}_{1} \mathrm{M}_{1} \mathrm{P}_{3}$ & 118.80 & 2.77 & 4.80 \\
\hline $\mathrm{T}_{1} \mathrm{M}_{1} \mathrm{P}_{4}$ & 118.61 & 2.26 & 4.83 \\
\hline $\mathrm{T}_{1} \mathrm{M}_{2} \mathrm{P}_{1}$ & 116.82 & 1.95 & 5.03 \\
\hline $\mathrm{T}_{1} \mathrm{M}_{2} \mathrm{P}_{2}$ & 117.71 & 2.04 & 4.92 \\
\hline $\mathrm{T}_{1} \mathrm{M}_{2} \mathrm{P}_{3}$ & 118.43 & 2.16 & 4.85 \\
\hline $\mathrm{T}_{1} \mathrm{M}_{2} \mathrm{P}_{4}$ & 118.21 & 2.12 & 4.89 \\
\hline $\mathrm{T}_{2} \mathrm{M}_{1} \mathrm{P}_{1}$ & 116.07 & 1.32 & 6.27 \\
\hline $\mathrm{T}_{2} \mathrm{M}_{1} \mathrm{P}_{2}$ & 116.11 & 1.83 & 6.24 \\
\hline $\mathrm{T}_{2} \mathrm{M}_{1} \mathrm{P}_{3}$ & 116.13 & 2.02 & 6.15 \\
\hline $\mathrm{T}_{2} \mathrm{M}_{1} \mathrm{P}_{4}$ & 116.21 & 1.97 & 6.18 \\
\hline $\mathrm{T}_{2} \mathrm{M}_{2} \mathrm{P}_{1}$ & 115.65 & 1.37 & 6.42 \\
\hline $\mathrm{T}_{2} \mathrm{M}_{2} \mathrm{P}_{2}$ & 115.71 & 1.83 & 6.37 \\
\hline $\mathrm{T}_{2} \mathrm{M}_{2} \mathrm{P}_{3}$ & 115.82 & 1.95 & 6.26 \\
\hline $\mathrm{T}_{2} \mathrm{M}_{2} \mathrm{P}_{4}$ & 115.93 & 1.92 & 6.31 \\
\hline $\mathrm{T}_{3} \mathrm{M}_{1} \mathrm{P}_{1}$ & 116.53 & 1.92 & 5.80 \\
\hline $\mathrm{T}_{3} \mathrm{M}_{1} \mathrm{P}_{2}$ & 117.71 & 1.95 & 5.73 \\
\hline $\mathrm{T}_{3} \mathrm{M}_{1} \mathrm{P}_{3}$ & 118.43 & 2.22 & 5.87 \\
\hline $\mathrm{T}_{3} \mathrm{M}_{1} \mathrm{P}_{4}$ & 118.21 & 2.22 & 5.67 \\
\hline $\mathrm{T}_{3} \mathrm{M}_{2} \mathrm{P}_{1}$ & 116.33 & 1.84 & 5.98 \\
\hline $\mathrm{T}_{3} \mathrm{M}_{2} \mathrm{P}_{2}$ & 117.03 & 1.86 & 5.98 \\
\hline $\mathrm{T}_{3} \mathrm{M}_{2} \mathrm{P}_{3}$ & 117.12 & 2.23 & 5.92 \\
\hline $\mathrm{T}_{1} \mathrm{M}_{2} \mathrm{P}_{4}$ & 117.51 & 2.18 & 5.95 \\
\hline MEAN & 117.07 & 1.98 & 5.68 \\
\hline $\mathrm{CD}_{0.05}$ & 0.0145 & 0.142 & 0.0282 \\
\hline Initial Value & 119.94 & 2.8 & 5.92 \\
\hline
\end{tabular}

$\mathrm{T}_{1}$ - Harvesting at morning $7.00 \mathrm{am}-9.00 \mathrm{am}$

$\mathrm{T}_{2}$-Harvesting at afternoon $12.00 \mathrm{pm}-02.00 \mathrm{pm}$

$\mathrm{T}_{3}$-Harvesting at evening $04.00 \mathrm{pm}-06.00 \mathrm{pm}$

$\mathrm{M}_{1}$ - Harvesting without pedicel

$\mathrm{M}_{2}$ - Harvesting With pedicel
$\mathrm{P}_{1}$ - Pre treatment without $\mathrm{CaCl}_{2}$ (Control)

$\mathrm{P}_{2}$ - Pre treatment with $0.5 \% \mathrm{CaCl}_{2}$

$\mathrm{P}_{3}$ - Pre treatment with $1.0 \% \mathrm{CaCl}_{2}$

$\mathrm{P}_{4}$ - Pre treatment with $2.0 \% \mathrm{CaCl}_{2}$ 
Fig.1 Effect of different time of harvest, method of harvest and pre packaging treatment with $\mathrm{CaCl}_{2}$ on ascorbic acid content during storage of Moringa cv.PKM 1

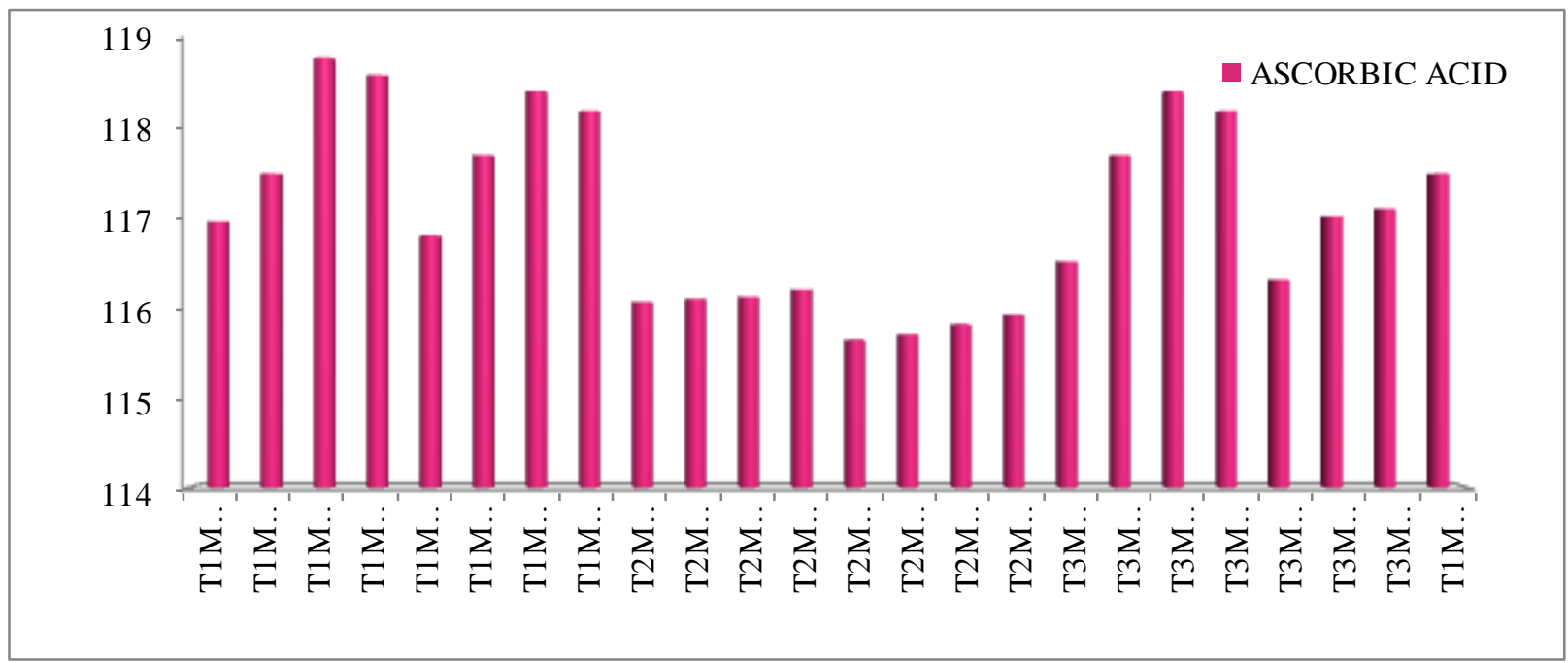

Fig.2 Effect of different time of harvest, method of harvest and pre packaging treatment with $\mathrm{CaCl}_{2}$ on protein $(\mathrm{mg} / 100 \mathrm{~g})$ and crude fiber $(\mathrm{g} / 100 \mathrm{~g})$ content during storage of Moringa cv.PKM 1

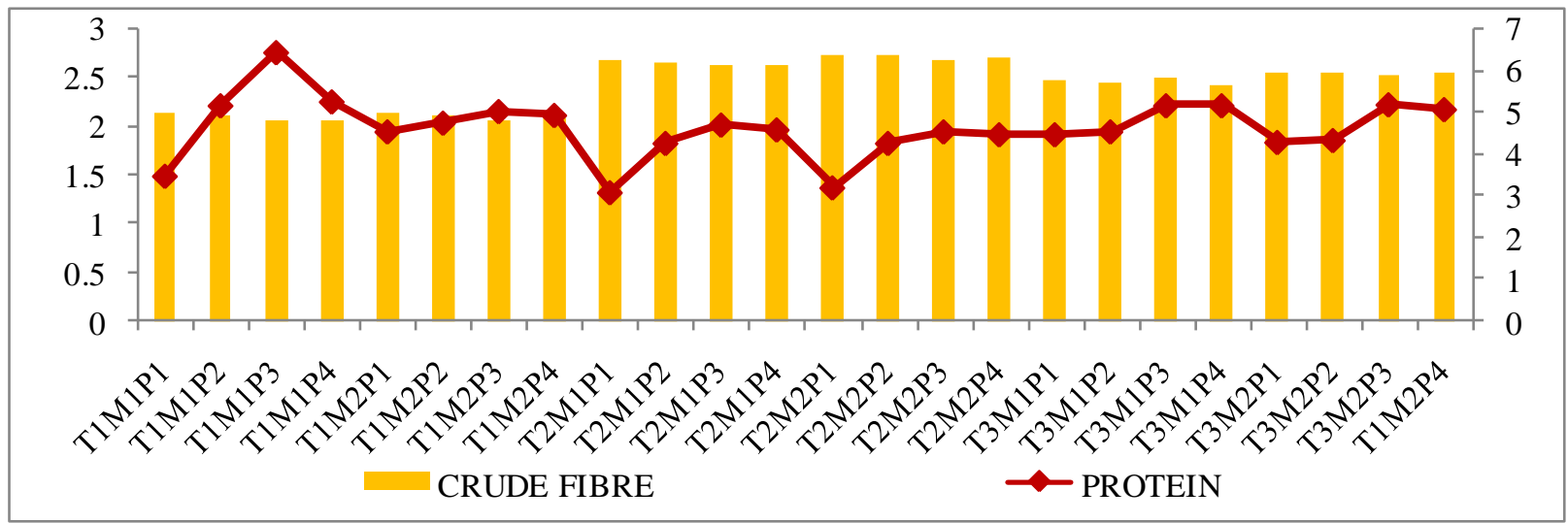

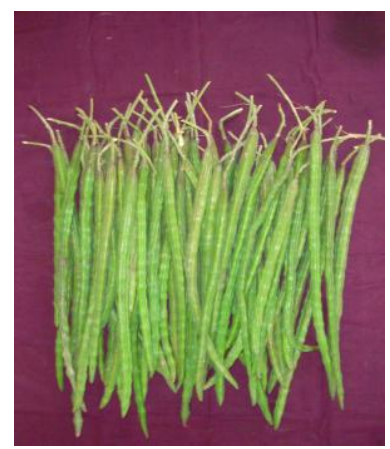

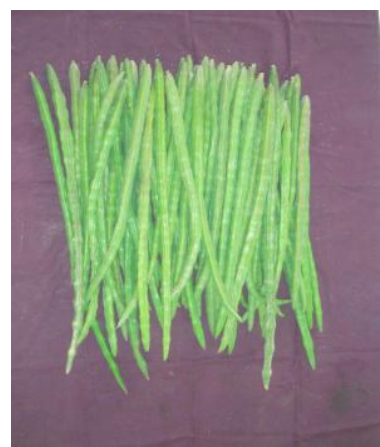

Plate.1 Harvesting of Moringa with and without pedicle

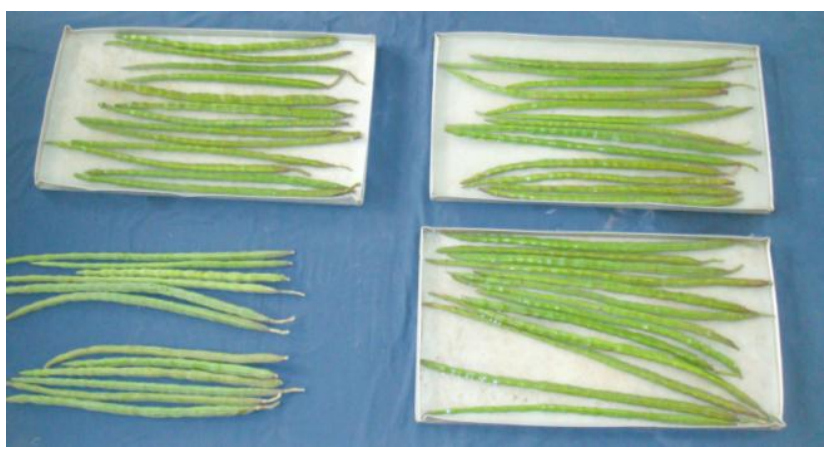

Plate. $2 \mathrm{CaCl}_{2}$ treatment of Moringa at various concentration 
The time of harvest and method of harvest had significant influence on nutritional changes during storage. The morning harvested pods with pedicle retains more nutrients when compared to afternoon and evening harvested pods. This might be due to the water loss was minimum in morning harvested pods because of less field heat. So the evaporation of nutrients from the moringa pods was also less. The evaporation starts from the pedicle so the nutrient evaporation from the pods is slower when compared to the pods harvested without pedicle. Similar results were found in red pepper by Simal (2005) red pepper. The reduction in nutrients was decreased in calcium chloride treated pods. This might be due to the effect of calcium which on deposition on the cell wall as calcium pectate made the cell wall to become thick (Wiriya, 2009).

The combined effect of morning harvest with pedicle and pre packaging treatment with calcium chloride had significant influence on the nutritional changes viz., ascorbic acid, crude fibre and protein during the storage of moringa. This might me due to reduction in moisture loss along with calcium pectate formation in the cell wall influenced the slow down.

\section{References}

Ali, B. 2004. Determination of acceptable firmness and colour values of tomatoes. J. Food Engin., 61: 471-475.

Davoodi, M.G., Vijayanand, P., Kulkarni, S.G., Ramana, K.V.R. 2007. Effect of different pre-treatments and dehydration methods on quality characteristics and storage stability of tomato powder. Food Sci. Tech., 40: 1832-1840.

Faizi, S., B.S. Siddiqui, R. Saleem, K. Aftab, F. Shaheen and A.H. Gilani. 1998. Hypotensive constituents from the pods of Moringa oleifera. Plant Med., 64:
225-228.

Giraldo, L.F., R.A. Forero, C.R. Salazar and R. Torres. 1977. The effect of packaging and potassium permanganate on the storage of tomatoes under room conditions. Hort. Abstr., 12(4): 393405.

Hameed-Un-Nisa, L., D. Shehnaz and S. Faizi. 1998. Measurement of sympatholytic activity of Moringa oleifera. New Trends in Natural Products Chemistry $\left[6^{\text {th }}\right.$ International Symposium on Natural Products Chemistry] 269-277.

Jackson, M.L. 1973. Soil chemical analysis. Prentice Hall of Indian Pvt. Ltd. New Delhi.

Maynard, A.J. 1970. Methods in food analysis, Academic press, New York, p: 176.

Palada, M.C. and L.C. Changl. 2003. Suggested cultural practices for Moringa. International Cooperators Guide AVRDC, 3: 545. www.avrdc.org

Pathak, V.N. and D.N. Shrivastava. 1969. Epidemiology and prevention of diplodia stem end rot of Mango Fruits. Phytopathol., 65: 164-175.

Pradnya, A., P. Sonali. 2008. Patel microbiological analysis of fresh vegetables \& fruits and effect of antimicrobial agents on microbial load. $J$. Food Microbial, 99: 71-77

Rakhshinda Panda, Himadri Panda, Kavita Prakash, Arundhati Panda. 2010. Prospects of Indian Chillies. Dept. of Chemistry, Bareilly (U.P.) India.

Samuel, A., C. Paul, Struik, Heuvelink and Woldeamlak Araia. 2011. Opportunities and constraints of tomato production in Eritrea. African J. Agri. Res., 6(4): 956967.

Simal, S., C. Garau, A. Femenia and C. Rossello. 2005. Drying of red pepper Capsicum annuum): Water desorption and quality. Int. J. Food Engin., 1(4): 
$10-22$.

Singh, B.P., S.K. Palra and D.K. Tonden. 1993. Effect of method of harvesting on storage behaviour of Mango. Indian J. Hort., 50(1): 5-9.

Singh, K. and U.B. Panday. 1993. Export of vegetables status and strategies. Prog. Hort., 21(2): 60-65.

Tirmazi, S.I.H. and R.B.H. Wills. 1982. Use of calcium to delay ripening of tomatoes. Hort. Sci., 12(6): 551-552.
Vijayakumar, R.M., M. Vijayakumar and N. Chezhiyan. 2003. Studies on pod characteristics of annual moringa cv. PKM-1 as influenced by seasonal changes and growth regulators. Madras Agric. J., 90(1-3): 149-151.

Wiriya, P., T. Paiboon and S. Somchart. 2009. Effect of drying air temperature and chemical pre-treatment's on quality of dried chilli. Int. Food Res. J., 16: 441454.

\section{How to cite this article:}

Sangeetha, V., V. Swaminathan, A. Beaulah, A. Rajkumar and Venkatesan, K. 2017. Effect of Time of Harvest, Method of Harvest and Pre Packaging Calcium Chloride Treatments on Shelf Life and Quality of Moringa (Moringa oleifera Lam.) CV. PKM 1. Int.J.Curr.Microbiol.App.Sci. 6(4): 212-221. doi: https://doi.org/10.20546/ijcmas.2017.604.025 